S. Kalantaievska ${ }^{1}$, O. Malyk ${ }^{2}$, M. Tiurnikov ${ }^{3}$, P. Zhuk ${ }^{4}$, A. Shyshatskyi ${ }^{5}$, R. Pikul ${ }^{4}$

${ }^{1}$ Military institute of telecommunications and informatization named after Heroes of Kruty, Kyiv, Ukraine

${ }^{2}$ General Directorate of the National Guard of Ukraine, Kyiv, Ukraine

${ }^{3}$ Military unit A0106, Kyiv, Ukraine

${ }^{4}$ National Defence University of Ukraine named after Ivan Chernyakhovsky, Kyiv, Ukraine

${ }^{5}$ Central Research Institute of Weapons and Military Equipment of Armed Forces of Ukraine, Kyiv, Ukraine

\title{
FOUNDATION THE WAYS OF RADIO ELECTRONIC WARFARE DEVICES DEVELOPMENT
}

\begin{abstract}
The development of radio-electronic warfare systems becomes the most effective, fast-performing, costeffective, and sometimes the only possible devices, which neutralizes the technical advantage of the opposite side in the information and technology spheres. The main increase in combat potentials in the near future will be possible through the use of intelligent command and control systems for troops and weapons, as well as the use of weapons that use unconventional devices of influencing the enemy. The authors of the research found that equipping weapons with the devices and complexes of electronic warfare can repeatedly increase their combat potential and reduce possible losses. In this case, the cost of electronic warfare technology is one percent in relation to the cost of major types of weapons. In the course of the research, the authors used the basic provisions of the theory of electronic warfare, the theory of communication, the theory of signals, and general scientific methods of analysis and synthesis. The authors found that the most important areas of research for the development of electronic warfare systems are: integration of forces and devices of electronic warfare with an intelligence and fire damage in a single information and communication space of all types of armed forces; creation of systems of radio engineering intelligence (passive location) for the reliable disclosure of electronic equipment and high-precision location of objects; Improvement of signal monitoring system in various physical fields. The principal features of the construction of advanced devices and complexes of electronic warfare are: ultra-wide radio engineering part of the equipment (more than 3 octaves); necessity of realization of parallel signal processing of received radio signals in the instant band of frequencies equal to several gigahertz; the maximum increase in the functional density of the apparatus implementation to reduce its mass and overall performance and ensure the possibility of its system integration; limit unification of basic digital elements of equipment, which allows to reduce the cost, facilitate the processes of modification and modernization of equipment. Taking into account the above, the direction of further research should be considered the development of methods for increasing the effectiveness of radio-electronic suppression.
\end{abstract}

Keywords: radio communication systems; radio resources; noise immunity; radio-electronic suppression; radioelectronic intelligence; secrecy.

\section{Introduction}

The development of electronic warfare systems (REW) is becoming the most effective, fast-selling, cost-effective, and sometimes the only possible devices of neutralizing the technical superiority of the opposing side in the information and technological areas. The main increase in combat potentials in the near future will be possible through the use of intelligent systems of command and control of troops and weapons, as well as the use of devices of warfare using non-traditional methods of influencing the enemy.

Such devices of warfare include, first of all, REW equipment, which is a complex object, characterized by high technology intensity. Modern devices, complexes and REW systems at the present stage of development are in a state of intensive improvement. In the long term (2020-2025 years), the volume of tasks assigned to REW funds will not only not decrease, but even increase due to a quantitative increase in the objects of influence and an increase in methods of influence on them [1].

Equipping weapons with REW equipment and complexes can multiply their combat potential and reduce potential losses. At the same time, the cost of REW equipment is a few percents in relation to the cost of the main types of weapons [1-4].

The purpose of this article is assigned to the fields of the future development of radio-electronic warfare.

\section{Presentation of the main material}

From a fairly wide range of tasks facing modern REW complexes, we can distinguish the tasks that determine the number of their fundamental features [5-7]:

- "hard" expediency of overlapping the ranges of operation of all radar location stations (RLS) detection, targeting, weapons control, as well as radio electronic systems (RES) communication and navigation;

- the functional need for the simultaneous implementation of a large number of complex tasks reception and high-precision analysis of the RES signals, determination of their coordinates, type, mode of operation and degree of danger, suppression of several RES, interaction with other complexes (primarily radio and radio engineering intelligence (RREI) and fire losses).

These tasks determine the fundamental features of the construction of promising devices and REW complexes [5-14]:

- ultra-broadband radio part of the equipment (more than 3 octaves);

- the need to implement parallel signal processing of received radio signals in the instantaneous frequency band equal to several gigahertz;

- the maximum increase in the functional density of the equipment to reduce its weight and size indicators and ensure its system integration; 
- the maximum unification of the basic digital elements of the equipment, which allows reducing the cost, to facilitate the processes of modification and modernization of the equipment.

These features promising hardware tools and REW complexes determine the feasibility of its construction on the basis of digital ultra-wideband signal processing devices, which allow to realize the above features to the maximum extent and additionally get the ability to quickly restructure the processing equipment by overwriting signal processing projects in programmable logic integrated circuits (PLIC) [5].

Thus, the future development of REW systems and facilities is closely linked to the use of the latest information technologies, which should provide the desired efficiency in the context of qualitatively changing requirements for devices and methods of warfare. Thus, in promising REW systems, functional and instrumental integration of on-board radio-electronic equipment (REE) with electronic countermeasures devices (ECD) and detection systems using other physical principles of operation (optical-electronic equipment, infrared (IR) and ultraviolet (UV) systems, etc.).

With the development of integrated onboard systems, the extensive logic of switching the modes of the integrated subsystems becomes complicated, which makes it possible to influence this process with the help of so-called algorithmic influences. In addition, despite the rapid development of digital technology, a memory bottleneck and speed of onboard computing systems will always remain a bottleneck, which will also allow producing algorithmic effects for the purpose of information overload on-board processors [7].

Thus, the development of REW equipment is largely determined by two interrelated scientific and technological areas of development of the elemental base of modern radio electronics [4]:

1. The creation of high-speed processors and computing systems, taking into account the latest achievements of microelectronics.

2. Expanding the possibilities of digital signal processing, which ensured the conversion of an aggregate of REW devices into high-speed digital systems.

The REW complex, functioning in modern conditions, should almost instantly respond to sudden threats. The response of the complex to the threat should not exceed $0.05-0.1 \mathrm{~s}$. Only digital electronic computers (DEC) with high speed and large amounts of memory are able to manage the resources of REW complexes, including [4, 7-9]:

- a set of active jamming stations;

- expendable devices of generating interference (towed active traps; anti-radar guided missiles; one-time interference transmitters; dipole reflectors illuminated by an interfering signal; projectiles with electromagnetic warheads);

- a set of types of interference and methods of their combat use;

- devices of functional RES damage;

- distribution of the energy potential of active jamming stations for the simultaneous suppression of several RESs;
- the ability to quickly change the orientation and width of the radiation pattern of antennas (phased antenna arrays) of active jamming stations in specified sectors of space;

- the ability to control the sequence of time intervals of interference to several RESs by one leading active interference station.

At the same time, there is a tendency to unite numerous radio engineering and optoelectronic devices (devices of radiolocation, electronic warfare, radio navigation, data transmission, infrared and other information sensors) placed on one carrier (aircraft) into a single integrated radio electronic complex [4].

Among the existing problems of creating promising systems and REW systems, three groups can be distinguished, differing in content and technology of their solution [7]:

- energy;

- informational;

- functional.

The essence of the energy problems lies in the complexity of the implementation of the required energy characteristics of REW complexes under the given constraints (in terms of mass, dimensions, energy consumption) and the existing element base. One of the main ways to solve them is to use active phased antenna arrays (AFAA) with high gain. The principal features of constructing an AFAA for the REW equipment are [7]:

- the possibility of adaptive control of the antenna pattern shape for the implementation of various modes of operation and the formation of "dips" in the direction of the sources of active interference;

$-7-8$ times extended working frequency band (30-40\% of the center frequency for AFAA and $5-6 \%$ for FAA);

- increased by 15-20 times the radiation power taken from the same aperture;

- the need for the simultaneous formation of several independent rays for the maintenance of spatially separated objects of influence;

- significantly reduced losses (up to $15-17 \mathrm{~dB}$ ) during signal processing;

- conformality and low effective area of diffusion;

- high reliability (average time between failures is comparable to the life of the aircraft).

The use of AFAA in the composition of REW complexes in the presence of the corresponding element base (high-power semiconductor microwave amplifiers and switches) allows obtaining the energy potential of almost any level. Calculations show that in the near future if there is a corresponding electronic component base, an active interference station with an energy potential of up to $1010 \mathrm{~W}$ can be created [7].

Information problems are due to the fact that the technical characteristics of an existing electronic intelligence system often do not allow to organize information support for the REW systems and devices at the proper level. First of all, this refers to the reliability of determining the objects of impact and the assignment by them of the corresponding service priorities while operating in a complex, dynamically changing electronic environment [5]. 
The solution to this problem is seen in translating most of the components of electronic intelligence equipment into digital processing. At present, the possibilities are being explored of improving the efficiency of high-speed digital REW equipment based on PLICs with a transition at the stage of mass production to the specialized "system-on-chip" [5].

Functional problems are primarily associated with the need for the simultaneous (quasi-simultaneous) suppression of radio-electronic devices that have different spatial and signal features, with a strict limit on the time of electronic conflict. These difficulties can be overcome by applying [7]:

- antenna devices with independent control of spatial interference channels;
- multichannel transceiver devices operating in a wide frequency range with parallel channel analysis;

- high-speed digital radio frequency memory (DRFM) systems.

In the future, it is important to create DRFM systems on basic construction in terms of the unification of its technical parameters for the use by most developers of REW equipment. In the new technology of electronic warfare, based on AFAA with digital beamforming, the system will be integrated with interference suppression devices in the format of smallsized AFAA transceiver modules [7].

Fig. 1 shows the dynamics of the expansion of the type of interference generated by modern REW complexes [5].
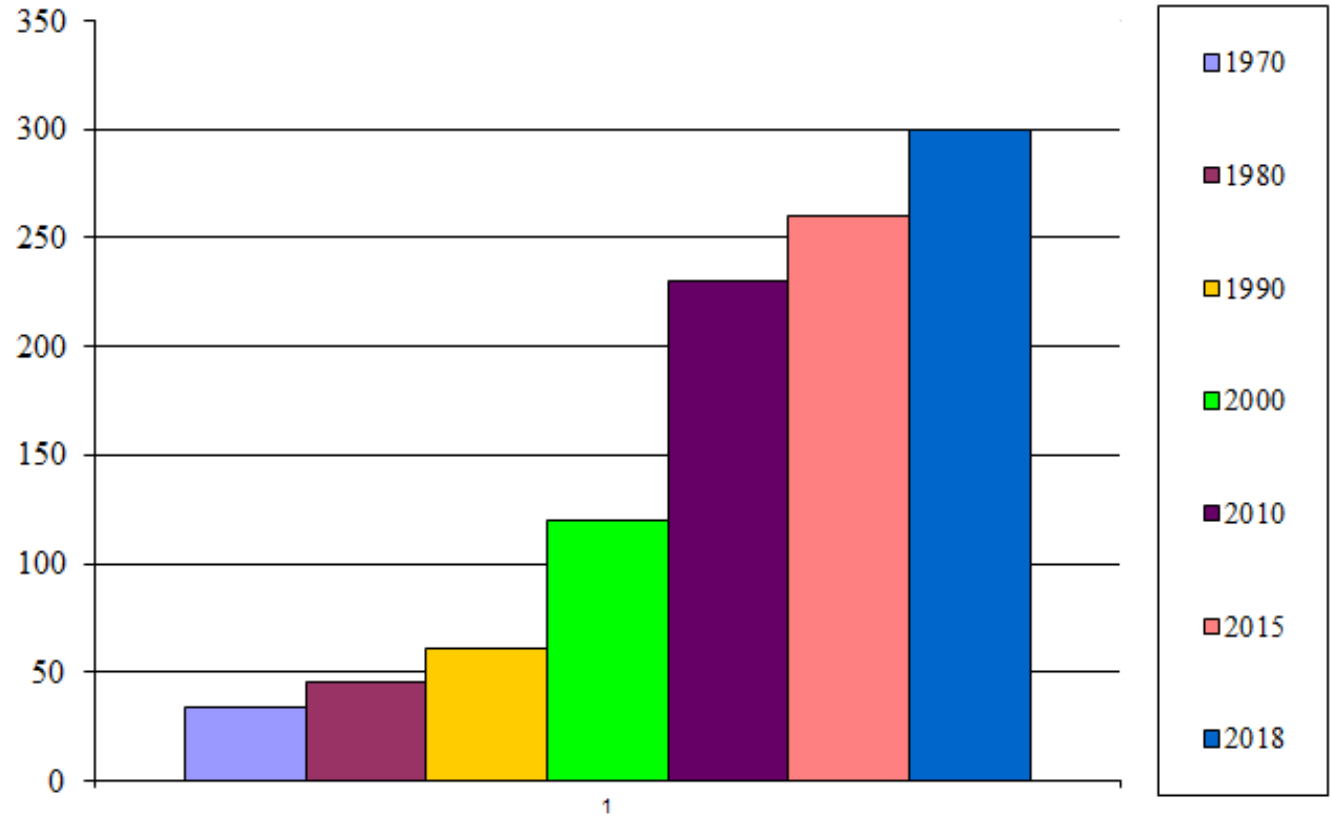

Fig. 1. The dynamics of the expansion of the type of interference generated by modern REW complexes

Expansion of the generated interference range allows you to implement an "individual approach" to the suppression of each specific RES. At the same time, in connection with the saturation of armaments with radio electronics, the number of radio electronic devices in service is constantly growing while increasing the number of modes of their operation. In this regard, in the near future, the technological limit of the range of generated interference, focused on specific RES and individual modes of their operation, will be reached. At the same time, the search for new ways to form interference modes for REW complexes will become topical.

In this regard, interesting research focused on the development of new methods of selective suppression of RES - "cognitive suppression". New methods of jamming should ensure the suppression of a wide range of enemy's RES (connected, navigation, radar, etc.) using modern devices and methods of electronic protection, while not disrupting the operation of their own radio and allied forces, as well as RES civilian. It is assumed that such jamming stations can be installed on specialized REW aircraft and on conventional strategic and tactical aircraft to ensure their individual electronic protection [2]. One of the most promising trends in the development of REW is the integration of air, land, sea and space REW facilities into a single network.

The concept of integration is based mainly on the development of digital radio technical intelligence (RTI) technology and active electronic suppression.

It is possible to instantly identify the radiation source and, if necessary, to create interference in various ways [2]:

- point setting low-power active interference;

- use of false information objects (false targets or messages);

- the introduction of packages of algorithms that can take command of the enemy's networks and, possibly, control of the enemy's sensors.

In addition, a promising direction of REW is to change the conditions of propagation and reflection of the electromagnetic waves. In this connection, the creation of special munitions with aerosol filling, which provide for changing the conditions of propagation of 
radio waves and affecting the operation of the RES, is relevant. New special compositions of aerosol systems are being developed, which provide to weaken the electromagnetic field intensity, and new compositions and coatings, providing intensive absorption of electromagnetic waves [5].

At the same time, methods and devices for spatialsignal imitation of protected objects with the aim of diverting attacking elements and devices for spatialsignal selection of interfering signals [5] are being developed to protect their own electronic equipment and optical-electronic devices from homing weapons and active interference in various ranges.

The most important research directions for the development of REW systems are presented below [5].

1. Integration of the REW forces and facilities with the devices of reconnaissance and fire destruction in a single information and communication space of all types of armed forces:

- implementation of network-centric systems for collecting, processing and communicating information about REE to consumers;

- introduction of secure computer technologies for analysis of REE and decision making;

- development of algorithms and decision support programs based on artificial intelligence methods.

2. Creation of RTI systems (passive location) for the reliable opening of electrical equipment and highprecision positioning of objects:

- creation of correlation-base difference and distance measuring complexes of passive location;

- development of single-point complexes, which significantly increase the accuracy of determining the location of targets by measuring the steepness of the front of the incident wave;

- creation of artificial intelligence systems for the analysis of REE.

3. Improving the monitoring system of signals in various physical fields:

- creation of unified state infrastructure for collecting, summarizing and communicating the results of monitoring;

- providing monitoring in the radio frequency and optical bands.

Analyzing the development trends of technologies for the development and creation of new radioabsorbing materials, it can be noted that modern absorbing materials will provide in the near future [5]:

- the reflection coefficient of electromagnetic radiation (in the range 1-10 GHz) of the order of 30-40 $\mathrm{dB}$, regardless of the direction of sensing and polarization of the signal;

- the reflection coefficient in the UV, visible and IR ranges is less than $0.1 \mathrm{~dB}$, and the reflection will have a diffusion character.

It can be predicted that in the nearest future, multifunctional masking coatings will be created, operating simultaneously in the radar, UV-optical and IR-wavelengths [5].

Taking into account the fact that about $80 \%$ of REW facilities are aviation protection equipment against air defense systems and they are aimed at suppressing RLS and optoelectronic controls, target designation and guidance of these systems, below these tools and REW complexes are presented in details.

The main directions of development of radio electronic destruction systems are given below:

1. Creation of a new class of complexes combining the capabilities of electronic intelligence, weapons control and interference stations. Implementation of information and hardware integration of tasks in the interests of creating devices operating in the following modes: RLS and weapons guidance; AFAA; jamming.

2. Creation of spatially distributed systems of radio-electronic protection of objects and their signal masking. Development of an active jamming system that forms a false signal and information environment in the grouping to protect its troops and masking objects.

3. The creation of a solid-state elemental base of a new generation in the interests of increasing the effectiveness of REW facilities. The creation of a number of AFAA broadband based on solid-state receivingtransmitting modules in a hybrid monolithic design.

4. The development of new sections of the radio frequency and optical bands:

- creation of electro vacuum and solid-state broadband receiving-transmitting equipment of the millimeter and submillimeter ranges;

- the creation of highly effective devices of reconnaissance and suppression in the IR and UV ranges.

5. Creation of new carriers for the placement of REW facilities, providing an increase in the range of reconnaissance and suppression.

The development of a new generation of unmanned aerial vehicles and the use of algorithms based on artificial intelligence.

\section{The conclusion from the article}

In the conditions of "total informatization", the concept of network-centric war as a strategic view on the conduct of the war in the new military-technical conditions became widespread. At the same time, this concept is vulnerable to the devices of informational REW systems impact. REW systems can provide a decisive advantage in a future network-centric war and level off the advantage of a technologically more advanced adversary. Thus, the concept of networkcentric wars brings to a new qualitative level: the new environment of military confrontation is the information space, and a new type of weapon is the information weapon.

This article analyzes the trends in the development of REW systems. Currently, REW is the oldest and most methodologically developed area of confrontation due to the impact on the information parameters of the conflicting military-technical systems. According to the authors, the REW theory for more than a century of its active development that contains testings and highly effective ways of influencing information technology systems based on information exchange destabilization.

Thus, the development of the theory of information confrontation (especially in the technical sphere) should be based on the scientific and methodological reserve in this area. 
Taking into consideration the above, the direction of further research should consider the development of methods for improving the efficiency of radioelectronic suppression of electronic equipment.

\section{REFERENCES}

1. Makarenko, S.I. (2017), Informational confrontation and electronic warfare in network centric wars of the XXI century, Monograph, High Technologies, Saint Petersburg, $546 \mathrm{p}$.

2. Bogdanovich, V.Yu., Svida, I.Yu. and Syrotenko, A.M. (2018), "The concept of the integrated use of military and nonmilitary forces and means to ensure a sufficient level of military security of the state", Science and Technology of the Air Forces of the Armed Forces of Ukraine, No. 2(31), pp. 16-29, DOI: https://doi.org/10.30748/nitps.2018.31.02.

3. Radiyevskiy, A.G. and Sirota, A.A. (2004), Theoretical foundations of electronic intelligence, Nauka, Moscow, 329 p.

4. Shyshatskiy, A.V., Bashkirov, O.M. and Kostina, O.M. (2015), "Development of integrated systems and data for Armed Forces", Arms and military equipment, No 1(5), pp. 35-40.

5. Hatsenko, S.S. (2017), "Methodology for assessing the operational situation in automated control systems of troops under uncertainty", Science and Technology of the Air Forces of the Armed Forces of Ukraine, No. 1(26), pp. 101-105, DOI: https://doi.org/10.30748/nitps.2017.26.21.

6. Zhuk, O.G., Shyshatskiy, A.V., Zhuk, P.V. and Zhyvotovskyi, R.M. (2017), "Methodological substances of management of the radio-resource managing systems of military radio communication", Information Processing Systems, Vol. 5(151), pp. 16-25, DOI: https://doi.org/10.30748/soi.2017.151.02.

7. Len'shin, A.V. (2014), Airborne systems and radio-electronic suppression complexes, Scientific book, Voronezh, 590 p.

8. Popov, A.O. and Tverdokhlibov, V.V. (2014), "General tendencies of development of means of electronic warfare", Arms and military equipment, No. 4 (4), pp. 4-10.

9. Porkodi, V., Sivaram, M., Mohammed, A.S. and Manikandan, V. (2018), "Survey on White-Box Attacks and Solutions", Asian Journal of Computer Science and Technology, Vol. 7, Issue 3, pp. 28-32.

10. Kuchuk, G.A., Kovalenko, A.A. and Mozhaev A.A. (2010), "An Approach To Development Of Complex Metric For Multiservice Network Security Assessment”, Statistical Methods Of Signal and Data Processing (SMSDP - 2010), Proc. Int. Conf., October 13-14, 2010, NAU, RED, IEEE Ukraine section joint SP, Kiev, pp. 158-160.

11. Manikandan, V, Porkodi, V, Mohammed, A.S. and Sivaram M. (2018), "Privacy Preserving Data Mining Using Threshold Based Fuzzy cmeans Clustering", ICTACT Journal on Soft Computing, Vol. 9, Issue 1, pp. 1813-1816. DOI: https://doi.org/10.21917/ijsc.2018.0252

12. Ruban, I., Kuchuk, H. and Kovalenko, A. (2017), "Redistribution of base stations load in mobile communication networks", Innovative technologies and scientific solutions for industries, No 1 (1), pp. 75-81, DOI : https://doi.org/10.30837/2522-9818.2017.1.075.

13. Serhiienko, V.D., Popov, A.O., Zibin, S.D., Bychkov, A.N., Pidhorodetskyi, M.M. (2017), "Analysis of the state of the art of multifunctional electronic warfare means and complexes", Modern Information Technologies In the sphere of security and defence, No.1(28), pp. 135-143.

14. Kuchuk, G., Nechausov, S., Kharchenko, V. (2015), "Two-stage optimization of resource allocation for hybrid cloud data store", International Conference on Information and Digital Technologies, pp. 266-271, DOI : http://dx.doi.org/10.1109/DT.2015.7222982

15. Romanenko, I. and Shyshatskyi, A. (2017), “Analysis of modern condition of military radiocommunication system”, Advanced Information Systems, Vol. 1, No. 1, pp. 28-33, DOI: https://doi.org/10.20998/2522-9052.2017.1.05.

Надійшла (received) 18.02.2019

Прийнята до друку (accepted for publication) 29.05.2019

\section{Відомості ПРО АВTOPIB / АвOUT тHE AUTHORS}

Калантасвська Світлана Володимирівна - ад’юнкт науково-організаційного відділу, Військовий інститут телекомунікацій та інформатизації імені Героїв Крут, Київ, Україна;

Svitlana Kalantaievska - Doctoral Student, Military institute of telecommunications and informatization named after Heroes of Kruty, Kyiv, Ukraine; e-mail: kalantaevska75@gmail.com; ORCID ID: https://orcid.org/0000-0001-6426-2235

Малик Олег Станіславович - начальник служби, Головне управління Національної гвардії України, Київ, Україна; Oleg Malyk - Chief of Service, General Directorate of the National Guard of Ukraine, Kyiv, Ukraine; e-mail: o.malyk@ngu.gov.ua; ORCID ID: http://orcid.org/0000-0002-7093-4357

Тюрніков Михайло Миколайович - здобувач, Військова частина А0106, Київ, Україна; Mykhailo Tiurnikov - competitor, Military unit A0106, Kyiv, Ukraine; e-mail: na4grup@ukr.net; ORCID ID: http://orcid.org/0000-0002-6291-9819

Жук Павло Васильович - кандидат технічних наук, доцент, начальник наукового центру, Національний університет оборони України імені Івана Черняховського, Київ, Україна;

Pavlo Zhuk - Candidate of Technical Sciences, Associate Professor, Head of the Scientific Center, National Defence University of Ukraine named after Ivan Chernyakhovsky, Kyiv, Ukraine;

e-mail: juk2011@ukr.net; ORCID ID: http://orcid.org/0000-0002-9628-8074 
Шишацький Андрій Володимирович - кандидат технічних наук, начальник науково-дослідної лабораторії, Центральний науково-дослідний інститут озброєння та військової техніки Збройних Сил України, Київ, Україна;

Andrii Shyshatskyi - Candidate of Technical Sciences, Associate Professor, Head of the science-research laboratories, Central Research Institute of Weapons and Military Equipment of Armed Forces of Ukraine, Kyiv, Ukraine; e-mailierikon12@gmail.com; ORCID ID: http://orcid.org/0000-0001-6731-6390

Пікуль Ростислав Володимирович - слухач, Національний університет оборони України імені Івана Черняховського, Київ, Україна;

Rostislav Pikul - hearer, National Defence University of Ukraine named after Ivan Chernyakhovsky, Kyiv, Ukraine, Ukraine; e-mail: pikul11@ukr.net; ORCID ID: http://orcid.org/0000-0003-1791-8486

\section{Обгрунтування шляхів розвитку засобів радіоелектронної боротьби}

С. В. Калантаєвська, О. С. Малик, М. М. Тюрніков,

П. В. Жук, А. В. Шишацький, Р. В. Пікуль

Анотація. Розвиток систем радіоелектронної боротьби стає найбільш ефективним, швидкореалізовуваним, економічно вигідним, а часом і єдино можливим засобом, що нейтралізує технічну перевагу протилежної сторони в інформаційній і технологічній сферах. Основний приріст бойових потенціалів в найближчій перспективі буде можливий за рахунок використання інтелектуальних систем управління військами та зброєю, а також застосування засобів збройної боротьби, які використовують нетрадиційні способи впливу на супротивника. Авторами дослідження встановлено, що оснащення озброєння засобами і комплексами радіоелектронної боротьби здатне багаторазово підвищити їхній бойовий потенціал і знизити можливі втрати. При цьому вартість техніки радіоелектронної боротьби становить одиниці відсотків по відношенню до вартості основних видів озброєння. В ході дослідження авторами були використані основні положення теорії радіоелектронної боротьби, теорії зв'язку, теорії сигналів та загальнонаукові методи аналізу та синтезу. Авторами встановлено, що найважливішими напрямками досліджень для розвитку систем радіоелектронної боротьби є: інтеграція сил і засобів радіоелектронної боротьби із засобами розвідки і вогневого ураження в єдиному інформаційно-комунікаційному просторі всіх видів збройних сил; створення систем радіотехнічної розвідки (пасивної локації) для достовірного розкриття радіоелектронного обладнання і високоточного визначення місця розташування об'єктів; удосконалення системи моніторингу сигналів в різних фізичних полях. Принциповими особливостями побудови перспективних засобів i комплексів радіоелектронної боротьби є: надширокосмугові радіотехнічної частини апаратури (більше 3 октав); необхідність реалізації паралельної сигнальної обробки прийнятих радіотехнічних сигналів в миттєвій смузі частот, яка дорівнює кільком гігагерц; максимальне збільшення функціональної щільності виконання апаратури для зниження іiї масогабаритних показників і забезпечення можливості іiі системної інтеграції; гранична уніфікація базових цифрових елементів апаратури, що дозволяє знизити собівартість, полегшити процеси модифікації і модернізації апаратури. Враховуючи зазначене, напрямком подальших досліджень слід вважати розробку методів підвищення ефективності радіоелектронного подавлення.

Ключові слова: система радіозв'язку; радіоресурс; завадозахищеність; радіоелектронне подавлення; радіоелектронна розвідка; скритність.

\section{Обоснование путей развития средств радиоэлектронной борьбы \\ С. В. Калантаевская, О. С. Малык, М. Н. Тюрников, \\ П. В. Жук, А. В. Шишацкий, Р. В. Пикуль}

Аннотация. Развитие систем радиоэлектронной борьбы становится наиболее эффективным, быстро реализуемым, экономически выгодным, а порой и единственно возможным средством, которое нейтрализует техническое превосходство противоположной стороны в информационной и технологической сферах. Основной прирост боевых потенциалов в ближайшей перспективе будет возможен за счет использования интеллектуальных систем управления войсками и оружием, а также применением средств вооруженной борьбы, которые используют нетрадиционные способы воздействия на противника. Авторами исследования установлено, что оснащение вооружения средствами и комплексами радиоэлектронной борьбы способно многократно повысить их боевой потенциал и снизить возможные потери. При этом стоимость техники радиоэлектронной борьбы составляет единицы процентов по отношению к стоимости основных видов вооружения. В ходе исследования авторами были использованы основные положения теории радиоэлектронной борьбы, теории связи, теории сигналов и общенаучные методы анализа и синтеза. Авторами установлено, что важнейшими направлениями исследований для развития систем радиоэлектронной борьбы являются: интеграция сил и средств радиоэлектронной борьбы со средствами разведки и огневого поражения в едином информационно-коммуникационном пространстве всех видов вооруженных сил; создание систем радиотехнической разведки (пассивной локации) для достоверного раскрытия радиоэлектронного оборудования и высокоточного определения местоположения объектов; совершенствование системы мониторинга сигналов в различных физических полях. Принципиальными особенностями построения перспективных средств и комплексов радиоэлектронной борьбы являются: сверхширокополосные радиотехнической части аппаратуры (более 3 октав) необходимость реализации параллельной сигнальной обработки принятых радиотехнических сигналов в мгновенной полосе частот, равной нескольким гигагерц; максимальное увеличение функциональной плотности выполнения аппаратуры для снижения ее массогабаритных показателей и возможности ее системной интеграции; предельная унификация базовых цифровых элементов аппаратуры, позволяющей снизить себестоимость, облегчить процессы модификации и модернизации аппаратуры. Учитывая данное, направлением дальнейших исследований следует считать разработку методов повышения эффективности радиоэлектронного подавления.

Ключевые слова: система радиосвязи; радиоресурс; помехозащищенность; радиоэлектронное подавление; радиоэлектронная разведка; скрытность. 